\title{
Além da sopa de letrinhas
}

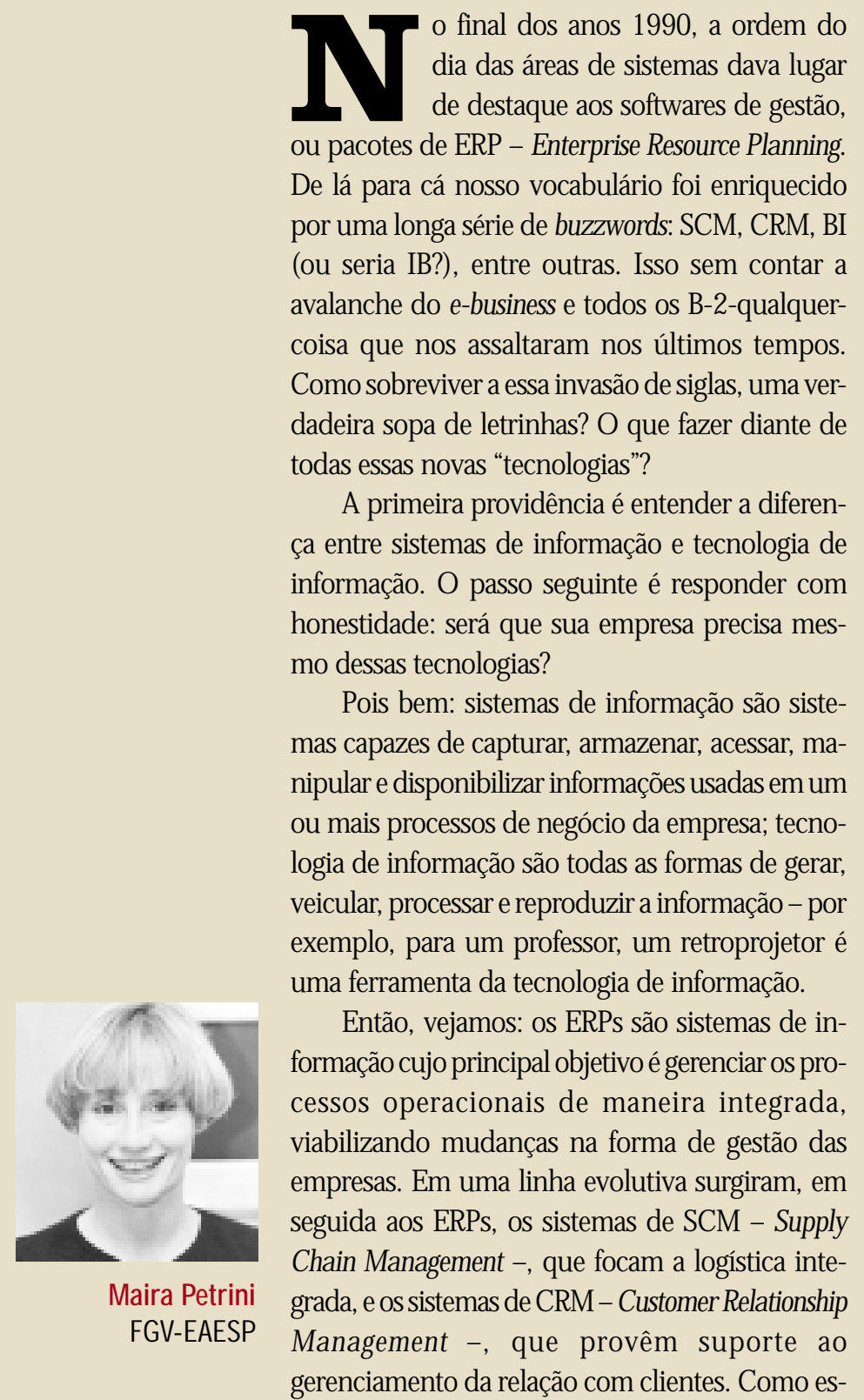

ses sistemas não têm capacidade para analisar as informações armazenadas, agregam-se a eles pacotes de BI - Business Intelligence - que fornecem ao executivo indicadores de desempenho que facilitam a tomada de decisão. 0 e-business, por sua vez, é um conceito abrangente que envolve um modelo diferenciado de negócio, geralmente associado ao comércio eletrônico, e que utiliza a Internet como tecnologia de informação.

Chegamos, finalmente, à pergunta: sua empresa precisa dessas tecnologias? Para essa questão, não há resposta padrão: cada caso é único. A mesma aplicação tecnológica, em contextos diferentes, pode ter resultados divergentes. 0 importante é que os sistemas de informação da empresa sejam coerentes com sua estratégia e seus processos de negócio. Exemplo: os pacotes de ERP foram durante al gum tempo vendidos com soluções integradoras e únicas, porém as implementações deERP têm comprovado queum único pacotede softwarenão écapaz de dar conta detodas as necessidades da empresa. Geralmente, o ERP convivecom outros sistemas que atendem a processos de negócio peculiares à companhia. Esse equilíbrio é que proporcionará o diferencial competitivo.

É possível, portanto, sobreviver à "sopa de letrinhas" da era da informação? Certamente! Como? Compreendendo que, embora necessária, a tecnologia não é fator determinante nem suficientepara a sobrevivência da empresa. Tecnologias de informação ou sistemas de informação não podem garantir o sucesso de uma organização - 0 que realmente importa é o uso que se faz deles. Primeiro, vem a estratégia de negócios; depois, todos os bits ebytes, ou seja lá que nomes tenham. 